\title{
The Standards of Proof In Medical MALPRACTICE CASES
}

Accepted
17.08. 2020
Revised
15. 09. 2020
Published
29. 10.2020

Keywords medical malpractice, expert evidence, standards of proof, no-fault system, civil procedure rules.

\author{
NINA CEK \\ Odvetniška družba Nina Cek o.p., d.o.o., Koper, Slovenia. \\ E-mail: nina@cek.si. \\ CORRESPONDING AUTHOR \\ nina@cek.si.
}

\begin{abstract}
The article examines the procedural aspect of medical malpractice cases. It focuses on the differences in standards of proof by first explaining the characteristics of the Slovenian legal system and then comparing it with German and English legal systems. The author sheds light on the approach of the EU court on the question of the responsibility of the manufacturer for the product (vaccine) and suggests the direction to use a broader framework for the evaluation of evidence and presumptions. Given the disclosed problems of proving through the help of a medical expert, the article emphasizes the importance of respect for human rights in civil proceedings. Particular emphasis is also placed on no-fault systems and the question is raised of how the introduction of such a system into the Slovenian legal system would affect the perceived problem of proving a medical error and informed consent omission.
\end{abstract}




\section{$1 \quad$ Introduction}

According to Slovenian legislation, the liability of the health care professionals depends on the claimant's ability to allege and to prove that there has been a breach in the treatment contract. The presumptive contract stipulates that the doctor should undertake professional care in order to help the patient recover, but does not guarantee the result (Žnidaršič Skubic, 2018: 80). In order to proceed with a complaint it is necessary to establish the causal relationship between medical conduct and the damage suffered by the patient, as well as to prove the existence and extent of the error. On the other side, in order to avoid liability, a medical professional must prove that he was unable to fulfill the contractual obligations due to circumstances that arose after the conclusion of the contract, and had no way of preventing, eliminating or avoiding them. ${ }^{1}$ With regard to the diligence of the physician, reference should be made to the professional norms and standards of conduct that apply in the medical field at the relevant time. The court, with the help of an expert, defines the content of these legal standards and norms and determines what is required by modern medical doctrine in a specific case, i.e. professional standards and norms with regard to the development of the health care system (Rijavec, 2017: 53).

It is extremely challenging to determine the cause of existing conditions and the facts, related to the omission of due diligence, through which advanced technology and very complex processes related to the medical treatment raise the risk of possible future damage. Another difficulty is also reflected in the informational and professional deficits the patient has in relation to the health care institution. The medical professional possesses concrete information about the treatment (even when it is not documented), as well as information from medical specialization sources, which is usually not available to the patient.

Proving that proper professional treatment could have prevented the natural course of an illness or injury is a particularly complex issue as it relates to debatable facts. In other words, there might exist two possible reasons that cause a bad result: either a mistake on the part of the professional party or a patient's preexisting condition. Understanding and proving which of the two caused the problem is very difficult.

\footnotetext{
${ }^{1}$ Article 240 of the Slovenian Code of Obligation (Obligacijski zakonik: Ur. 1. RS, št. 97/07, 64/16, 20/18).
} 
In the Slovenian legal system, the claimant bears the burden of proving all the aforementioned aspects, except the defendant's guilt. The conclusion is, therefore, that the patient's burden of establishing malpractice in medical civil law is anything but simple.

For these reasons, the legal system has been faced with the challenge of providing the patients with adequate legal procedures (procedural and substantive) in order to ensure them a fair trial. On the other hand, there has been a political, and even professional tendency, to protect the healthcare system from negative financial consequences which in turn could motiviate it to practice defensive medicine, the practice of which leads to performance of unnecessary tests, exams and referrals and the concomitant expenses associated with same (more on defensive medicine see Šepec, 2018: 56).

It is important to balance the rights and interests of patients, on the one hand, with those of health care professionals on the other hand, when establishing a system of compensation in medical error cases. In other words, the judicial system must establish a leval playing field. In civil trials, the judicial system has to deal with questions of both substantive and procedural law. Concerning procedural law, in this article we analyze the standards of proof which answer the questions about the degree of certainty of a fact that needs to be proven (Pavčnik, 2012: 1408). Since the success of medical treatment is very often uncertain, it can be exceedingly difficult to prove facts relating to liability, especially the causation element. A dilemma is whether the peculiarities and intricacies of medical malpractice cases justifies deviations from the usual proof requirements in other civil cases. From a comparative standpoint, as we shall see later in ths article, there has been a general worldwide shift towards easing the burden of proof. This view urges a reasonable assessment of the rules for claming liability and argues that the patient's burden of proof should not be impeded by overly strict requirements (Rijavec, 2017: 54).

\section{Standards of proof in civil litigation}

In the field of gnoseology, philosophy deals with analyzing whether a person is capable of knowing the truth about something. Its main tenet is that it is not really possible to achieve the absolute truth (Janžekovič, 1981). In litigation, during a court hearing, the judge is required not only to establish the truth, but also to sustain his 
ideas through the evidentiary assessment, through the claims and the evidence offered and presented by both parties in the court, so as to substantiate a reasoned judgment.

By processing the standards of proof, the court analyses and subsequentially reaches a verdict based on higher or lower probabilitities, not only on certainty. So, it is by the dexterity and decision of the judicial power that the presented proof is categorized as a certainty (Zobec, 2006).

The abovementioned gnoseological aspect is taken into consideration when the principle of material truth is put into question. In the theoretical civil procedural law of the Slovenian legal system the material proof can be classified in different ways (such as certain, believable, probable, and doubtful). It is through this system of stratification that the standards of proof are established. Generally in a civil trial, in order to conclude that a fact has been proven, is the fact finder must be satisifed to the legal standard of "beyond reasonable doubt," meaning that the fact occurred and that its true existence would not be questioned by any reasonable, experienced person (Pavčnik, 2012: 1410). Such a fact is believable to be true. In opposition to certainty, which represents the complete conformity of the subjective notion with the existing facts, a lower degree of conformity with reality is required in some cases during the litigation process. The third level of reality, probability, occurs when the reasons that speak on behalf of the truth of a particular fact outweigh the reasons that speak against them. This level of probability is defined by the standard "balance of probabilities" or "preponderance of evidence." A lower level of reality, doubt, arises when the reasons for and against the existence of a particular fact are equal.

Setting too high standards of proof is pointless as they cannot be achieved. Both Zobec (Zobec, 2006: 337) and Pavčnik argue, for example, that a claimant's right to a fair trial is placed into jeopardy when forced to submit proof at an unattainable level. Consequently in Slovenia recent legal practice has decreased the standards of proof in medical malpractice cases for two reasons; first, because the outcome of medical treatment is innately uncertain and second, because the claimant often is incapable of establishing a breach of the applicable standard of care due to a lack of information and knowledge, which, as we have already discussed, is in the exclusive possession of the healthcare providers (Pavčnik, 2012). 
In medical malpractice cases, facts that are related to a breach of duty, are normally assessed with the help of medical experts. This causes, due to professional solidarity, even more difficulties. Some legal theorists, due to the intrinsic difficulties associated with establishing professional errors in the field of medical care, coupled with the fact that medical care is, by its nature, an activity associated with increased levels of risk, have advocated applying the theory of strict liability, a theory traditionally reserved for establishing liability in cases involving inherently dangerous conduct (Polajnar-Pavčnik, 1998). ${ }^{2}$ However, the legal system has to date rejected that standard.

Instead, the Slovenian legal system found that a possible solution to this dilemma could be the so-called »softening« of the traditional rules on the standards of proof. This involves a different process in medical malpractice cases, designed to facilitate the patient's position as an injured party, and in realization that the patient is the weaker party in the relationship. Concomitantly, certain measures have been taken in the substantive field, in particular by establishing rules on the reverse burden of proof, as well as by simplifying the procedure necessary to establish causation (Žnidaršič Skubic, 2018).

\subsection{Balance of probabilities in medical malpractice cases}

In its decision II Ips 436/2005 of 21 June 2007, the Supreme Court of Slovenia stated that "the standard of proof is not a procedure that would be applied in advance as a common protocol in all cases and in all life situations." 3 We personally reached the following conclusion. Rigid procedural rules do not aid in the task of attempting to establish legal certainty. To the contrary, the judicial system's quest to "establish the truth" is enhanced only when the rules are fashioned in a way that track the diversity of life situations and adapt to their variety. Therefore, we believe that a change from the commonly used standard "beyond reasonable doubt" in medical malpractice cases is both necessary and desirable. The reason we advocate for this adaptation is to better protect the patient's position as a weaker party, substantive and compliant to the law. The position of the patient in litigation is significantly weaker than the position of the medical institution. Despite the fact that

\footnotetext{
2 The application of strict liability rules under Article 131 of the Slovenian Code of Obligation, according to which liability for damage from dangerous activity or objects is not based on fault.

${ }^{3}$ Decision of the Supreme Court of Republic of Slovenia, Judgment II Ips 436/2005 (21 June 2007), Paragraf 9.
} 
he does not have professional medical knowledge, he is obliged to prove that a medical error has ben committed, which also applies to proving the causal link between this error and the deterioration of his health condition. According to procedural rules, the patient's weaker position is evidenced by an objective inability to prove the cause-and-effect relationship between the error and what should have been the patient's improvement of health. Consequently, the patient resides in a state of so-called »evidentiary distress «. Additionally, the existence of the error must be proven by a medical expert. While intervention by an expert at least theoretically increases reliability due to the patient's lack of professional competence, this is not a full-proof solution by any means, due to the experts' so-called "professional solidarity", which may well, in at least some instances, lead to the expert, whether consciously or not, siding with the medical practitioner(s) and therefore in reality preventing claimant from establishing the necessary standard of proof (beyond reasonable doubt). According to Pavčnik (Pavčnik, 2012: 1414), this conundrum has led to a change in the previously established standard of proof from beyond a reasonable doubt to the balance of probabilities.

As is true with other standards, even the standard of proof needs to be explained with a content of concrete facts and evidence and explained by the court in a law case. Thus, in II Ips 17/2015 the Supreme Court of Slovenia (Vrhovno sodišče Republike Slovenije, point 15 of the decision), in analyzing the proof required in breach of contractual duties and the causation required in medical malpractice cases, affirmed that lower courts have been able to satisfy the standard of "balance of probabilities" by obtaining proof "exceeding 50 percent of probability" ${ }^{4}$, meaning that they were sufficiently able to prove that the facts really occurred. As shown, a mathematical principle of truth-finding was applied which, in our opinion, remains (at least in the concrete case) unexplained and exposes the decision of the court as arbitrary. Our opinion is premised on the fact that the arguments underpinning the court's decision were not presented sufficiently. We argue that in order to help ensure legal certainty, as well as the right to a just compensation, a descriptive approach is fundamental to help the court understand which facts outweigh others and what criteria are used in order to establish the truth. After all, the fundamental goal of any legal procedure is to help ensure all litigants are understood and to receive a fair trial. The court must therefore clearly state what facts are considered true and

\footnotetext{
${ }^{4}$ Decision of the Surpreme Court of the Republic of Slovenia, Judgment II Ips 17/2015 (29 October 2015).
} 
to what extent they contribute to establishing the truth, at least to the extent of halfprobability (balance of probabilities). If this standard is not met, the court should make a decision based on the burden of proof.

Furthermore, in its decision in II Ips 402/2007, the Supreme Court of Slovenia emphasized that the commonly accepted level of standard of proof, "beyond reasonable doubt," was too strict and not the only acceptable possibility, especially in cases where erroneous fact finding would equally affect both parties, but also in cases where the burden of proof would be too demanding for one party. ${ }^{5}$ The Court emphasized that proving the reasons behind a medical error is highly hypothetical and, consequently, it would be sufficient for the claimant to prove that the proper conduct of the medical professional would have significantly improved the patients medical status. ${ }^{6}$ Therefore in our view, the court should additionally explain why it considers that the reduced standard of proof (balance of probabilities) is sufficient (for example, it could affirm that proving causality means proving a hypothetical situation and not a true fact).

The standard, based on balance of probabilities, divides the risk of proof between the two parties, which inevitably distributes also the risk of the litigation, so that both parties have an equal chance at a positive outcome or equally risk a lawsuit. This more liberal standard thus substantially deviates from the idea of "unattainable gnoseological ideals" (Zobec, 2006). In medical malpractice cases, this more sustainable burden of proof is desirable. While it helps protect the patient as a weaker party in litigationconversely it cannot be said to negatively affect the stronger party in the relationship, the medical institution, since it possesses all the documentation provided by the professionals. The previously discussed situations create a significant advantage in the stage of expert proofing during the trial. In our opinion, by lowering the standards of proof, both parties are granted equal opportunities thus satisfying the notion of the equality of arms. At the same time, employing this lesser burden of proof does not adversely affect the healthcare institution's right to a fair trial. However, despite lowering the standards, the court needs to judge and sufficiently verify whether the patient was able (or not) to prove the facts concerning the specific elements of liability. In our judgment, utilizing the balance of the probabilities standard will not cause healthcare providers to engage in the practice

\footnotetext{
${ }^{5}$ Decision of the Surpreme Court of the Republic of Slovenia, Judgment II Ips 402/2007 (13 May 2010).

${ }^{6}$ Decision of the Surpreme Court of the Republic of Slovenia, Judgment II Ips 183/2015 (3 December 2015).
} 
of so-called defensive medicine or otherwise lead to evidentiary distress nor do we envision other negative effects on the legal position of the health care provider. To the contrary, using this standard will instead serve to efficiently equalize the position of both parties. In other words, whereas the current standard has titlted the playing in field unfairly (in our judgment) in the direction of the medical profession, instituting the balance of probabilities standard places both sides on a more level playing field, a situation that neither side should have concern with.

\subsection{Standard of balance of probabilities in cases related to informed consent}

Another assertive point in medical law cases is related to the omission of informed consent as a breach of a physician's duty to to the patient. In this instance, the patient claims that a failure to be properly informed of all the risks being undertaken by the treatment in question caused injury or harm. In such a case, the patient needs to prove a correlation (proximate cause) between the omission of information and the resulting damage allegedly caused by it. Therefore, it is necessary to distinguish between the burden of proof of the health care professional on the one hand, who has to prove that verbal consent was obtained (due to the patient's inability to prove the so-called negative facts), and on the other hand, the burden of proof of the patient, who has to establish a causal link between the omission of informed consent and the damage allegedly suffered.

In order to prove that verbal consent was given, Slovenian law (through the Patients' Rights Act) stipulated a form. ${ }^{7}$ The content of the form is standard, ${ }^{8}$ so consequently in our opinion, proving the existence of consent should not be a matter of lowering the standards of proof. Therefore, we recommend that it should be proven by the standard "beyond reasonable doubt." The medical professional should be considered an expert, who knows exactly what information should be given verbally to the patient and what, within the stated standard of care, must be recorded on a standard form. If the physician asks the patient to provide informed consent after having explained the information connected to the treatment (e.g., the risks, the planned course of action, any alternative options) and fills in the pre-prepared form properly, proving the existence of informed consent in a possible lawsuit will not cause

\footnotetext{
${ }^{7}$ Patients' Rights Act (Zakon o pacientovih pravicah - ZPacP), Ur. 1. RS, no. 15/08, 55/17.

${ }^{8}$ Defined in Pravilnik o obrazcih o pisnih izjavah volje pacienta Ur. 1. RS, no. 82/08, 84/08.
} 
disproportionate problems for medical institution. In proving the reason the patient was misinformed and the appearance of damage, the patient needs to claim and attest that he would have not approved of a specific treatment if he had been properly informed (about the risks, alternative options, etc.). The patient must attest that with a proper course of action he would not have suffered any harm, and that, accordingly, a causal link between the omission and the damage suffered exists. Even this situation is considered highly hypothetical however, as many times the treatment provided is meant only to improve the patient's medical condition, not to completely cure or resolve it. This is why the patient has to prove that if he had received proper information he would have either chosen an alternative treatment or ceased the current therapy and he would not have suffered as much harm. This is why we contend that even by proving the causation element in omission of informed consent cases, lowering the burden of proof standard is nevertheless necessary. The standard "beyond reasonable doubt" is unobtainable in this case and ought to be replaced by the "balance of probabilities" standard.

According to the available data, the Slovenian legal system has not encountered these issues so far, since it has always decided to lower the standard of proof in cases related to medical malpractice, and not in cases of omission of informed consent.

\section{Expert evidence in a civil court case}

The outcome in a civil trial involving professional medical malpractice depends mainly on proving both the causation element and liability through the help of a medical expert. Assessing the cause of death in one particular Slovenian medical malpractice case (Šilih), the European Court of Human Rights stressed the importance of providing an efficient and independent system that allows the determination of the causes of death of a patient under hospital care, and the liability of the medical professional under the protection of the right to life, Article 2 of the European Convention on Human Rights (ECHR). ${ }^{9}$ The court's justification, which was also taken up in the Decision Up-680/14 of the Constitutional Court of Slovenia, emphasizes that it is the government's obligation to provide the affected individual and claimant in the legal process with explicit and clear clarification on the cause of death, including liability on personal damage. Due to the mentioned

\footnotetext{
${ }^{9}$ Complaint to ECHR, Šilih v. Republika Slovenia, 4 September 2009. app. no. 71463/01.
} 
decision, it is necessary for the expert evidence to be presented in such a way so as to enable the claimant to "test the experts opinion in question, in order to attest if his work is complete, correct and comprehensive". ${ }^{10}$ As a consequence, in this judgment the Constitutional Court emphasized the necessity to have verbal testimony from an expert or the verbal confrontation with several experts at the trial, as long as the parties agree on the completeness of the examination and the professional reliability of the opinion. A direct dialogue between the court members, the experts and the parties is required to compare the possible differences of opinion, in order to remove doubts about its correctness and to achieve an appropriate standard of balance of probabilities. Therefore, it is undoubtedly essential to not only satisfy the lower standard of proof in cases of proving such hypothetical facts, but also to ensure that the general empirical facts, offered by the experts, are verifiable and coherent. In this regard, the Supreme Court of Slovenia, in the decision mentioned earlier, II Ips $183 / 2015$, pointed out that proving and applying the rules of burden of proof and the correct fulfillment of the requirements of the standard, ends when the doubt about causation (whether proper medical conduct would have prevented the damage) is answered by an expert. This is the case because of the professional nature of the issue. The expert opinions ensure that the court does not have to undertake additional research, since the expert opinions are the most relevant testimony and therefore establishes that the event did not and will not happen.

The moment in the trial when the process of expert proofing is concluded is a particularly sensitive part of litigation. The court is either convinced that the expert has answered any doubts on mistreatment, or it acknowledges the breach of informed consent. At the same time, however, it is within the prerogative of the parties to decide whether the opinion of the expert is correct and complete enough to reach such a conclusion, since (in pursuit of success) they might find themselves facing a procedural situation in which they need to call on a new expert. It is the court's function to eliminate the contradictions or deficiencies in the expert's opinion in compliance with Article 255 (3) of the Civil Procedure Act (ZPP-1) ${ }^{11}$. The judge should detect when it is necessary to involve another expert in the trial. Generally, however, this is not necessary unless the parties request it.

\footnotetext{
${ }^{10}$ Decision of the Constitutional Court of the Republic of Slovenia, Up-680/14 (5 May 2016).

${ }^{11}$ Civil Procedure Act (ZPP), Uradni list RS, št. 73/07.
} 


\section{Judgment C-621/15 of the Court of Justice of the European Union $(\mathrm{CJEU})^{12}$}

The Court of Justice of the European Union delivered a judgment on the 21 st June 2017 requested for a preliminary ruling under Article 267 TFEU from the French Cour de Cassation. The preliminary ruling was related to the interpretation of the EU Product Liability Directive, specifically whether the presumptions (a causal link may be presumed if a disease manifests itself shortly after administration of the allegedly defective drug and there are no personal or family antecedents related to the disease) are compatible with 'the Directive', furthermore if systematic application of those presumptions is compatible with the Directive, and, if not, whether scientific evidence of a causal link must be adduced by the claimant.

Claimants brought an action for extra-contractual liability against Sanofi, the manufacturer of the vaccine which, in their opinion, lead to multiple sclerosis of their relative who died in 2011. The Court stated that the burden of proof for product defection as well as for the causation was - according to Article 4 decree $85 / 374$ (»The Product Liability Directive) ${ }^{13}$, the claimant's responsibility (hence the burden was on the injured party). It noted that, with respect to the principles of equality and validity, the EU Members should establish the means to determine proof, the admissible evidence, the process through which the court analyses the evidence and the standard of proof required. However, the national rules should not prejudice the distribution of the burden of proof, and the claimant should be allowed to testify on the basis of evidence, meaning, if he can sufficiently prove it, the existence of a defect in the vaccine and the existence of a causal link between the defect and the harm suffered. In cases where medical research does not provide proof or excludes the existence of a link between the use of the vaccine and the onset of the disease, the claimant is allowed to present other factors (for example proximity of time and lack of illness in family history) to convince the court that there is a link. At the same time, the court noted that the evidence rules are not applied in a way that would, in practice, lead to an unproven supposition due to insufficient proof against the manufacturer. Instead, in order to consider the claim

\footnotetext{
${ }^{12}$ Court of Justice of the European Union, Judgment of the Court (Second Chamber) of 21 June 2017, N. W and Others v Sanofi Pasteur MSD SNC and Others.

${ }^{13}$ Council Directive 85/374/EEC of 25 July 1985 on the approximation of the laws, regulations and administrative provisions of the Member States concerning liability for defective products.
} 
proven, the evidence rules should be strictly adhered to so as to avoid accepting irrelevant or insufficient evidence, but instead attest that the submitted information is sufficiently serious, precise and consistent.

On the basis of the Court's judgment, we expect that this principle should apply not only in cases of manufacturer responsibility for a product, specifically for a vaccine, but also in cases such as proving a correlation between the damage and the medication or even the method of treatment and the resulting consequences.

After considering all of the circumstances, the Supreme Court of Slovenia, in its decision II Ips 182/2013, was compelled to conclude that insisting on a generally accepted standard "beyond reasonable doubt" in cases that involved proving negative evidence, would lead to a situation of evidentiary distress, making it necessary to facilitate the burden of proof by accepting all information as valid evidence. ${ }^{14}$

The presented judgment C-621/15 serves to confirm how important it is to lower the standards of proof in the trials of this nature, since they involve similar considerations and reasoning. It is readily apparent that certain facts cannot be reliably proven because of their hypothetical nature. This reality, however, should not affect the possibility of a successful outcome for the parties. On the contrary, it is necessary to insist on the equality of arms and to protect the defendant against the success of the plaintiff's accusations that are based only on assumptions and conjecture. We suggest that courts in civil procedures consider both pointed aspects.

\section{$5 \quad$ Comparative legal aspects}

Comparative legal systems, as is the case in the Slovenian legal system, expose the problem of proving due diligence and causation. In particular, both the theoretical and the practical side of a trial face the problem of proving causation, firstly because of the hypothetical improvement of the medical condition in the process of treatment, but also due to numerous possible causes of the resulting damage.

\footnotetext{
${ }^{14}$ Surpreme Court of Slovenia in judgment II Ips 182/2013 (24 April 2014).
} 
If we take the German and English legal systems for comparison, we will, first of all, find that in both systems the plaintiff has the burden of proof to estsblish both a breach of due diligence and causation (Stauch, 2008: 63). In both systems, the legal case has led to modifications of the general rules on evidence in civil proceedings, mainly because of the need to facilitate the patient's complicated position as weaker party, as previously discussed in this article.

\subsection{Proving medical malpractice in the English legal system}

The standard of proof in an adversarial system (in contrast with an inquisitorial system) is relatively low. It is based on a "Balance of Probabilities," meaning that a party who claims relevant facts and is responsible for the burden of proof, is required to attest that those facts are more likely to be true than untrue. The facts are to be considered real if the court considers that the events are more likely to have happened than not (Davies, 2009).

The English legal system enforced this standard with a "but for test," in other words a court determines causality by assessing whether the physician's conduct is in fact a direct cause of the harm to the patient's health and, in accordance with this rule, the patient is obliged to prove that if the treatment had not been negligent, the patient would not have suffered any damage (Žnidaršič Skubic, 2018: 81). In other words, "but for" the negligent conduct the damage would not have occurred. Ultimately, it is for the court to assess whether the injury would have occurred even had the medical professional exercised due diligence, was exercised, using the standard of balance of probabilities. In this regard, the English case law has repeatedly pointed to the 50 percent threshold of probability, which is a mathematical criterion that the court should have in mind when evaluating a verdict. Thus, in the East Berkshire AHA Hotson case, the court explained that in the case of a 55 percent chance that the patient would have fully recovered if he had not been treated wrongly, there still would have been a 45 percent chance of "non recovery" despite mistreatment. In this case claimant did not sufficiently prove that his injury was the result of negligent treatment. Such a view is particularly problematic because of the hypothetical consequences, as pointed out by Judge Lord Nicholls in his dissenting opinion in the Gregg v Scott case. He reasoned that a 45 percent chance of the loss of recovery is as real as a 55 percent chance of the loss of recovery. Assuming that in both cases the doctor breached the appropriate duty of care, in both cases the patient is worse 
than he was at the start, except that in one case he receives compensation and in the other case he does not. Therefore, the reasoning goes, the doctor's diligence loses its importance. (Stauch, 2008: 80). The dissenting opinion therefore favors the abandonment of the percentage assessment of the possibility of treatment success in medical error cases.

Proving medical errors in the English system is mainly a task entrusted to medical experts, who prepare the expert opinion after receiving a request by one or the other party. The claimant or the defendant (usually both) then present their opinion to the court and the court decides which opinion will be relevant in the final judgment.

The English legal process, as is true in Slovenia, uses both documentary materials (medical records) and witness hearings during the adjudicative process. Inequality between the two parties (since the healthcare institution possesses both documentation and expertise, and the patient does not), requires the healthcare institution to provide all available documentation, including anything that demonstrates its contra legem artis or "unlawful" behavior (Stauch, 2008: 68; Vojković, 2019). In England, the final task is that of editorial duty, and after the case management conference the parties need to prepare a list of documents they possess and specify which documentation the opposing party requests to have access to. In case of defective documentation (if it is missing or illegible) the court is obliged to reconstruct the missing data (through hearings, etc.). If the court establishes that the documentation was falsified, the doctor is accused of acting negligently. The Slovenian legal system is not familiar with this sort of reasoning. However, we can find some similarities in the Article 227, paragraph 5 of the Civil Process Act (Zakon o pravdnem postopku). Under this provision, if the consulted party, who possesses the document, refuses to deliver it to court, the court is allowed to consider that the document exists, and that its content coincides with what is claimed by the opposing party. Another similarity between the Slovenian legal system (Article 236a of the Civil Procedure Act), and the English system, is that they both request written statements from the witnesses prior to a direct hearing. The difference is that under the Slovenian system, requesting written witness statements is optional, whereas in an English legal case it is mandatory (Stauch, 2008: 80). 
Furthermore, the English legal system has established decision-making to be compliant to the doctrine of res ipsa loquitur (Lat. an object speaks for itself) (Kranjc, 1998: 220), which enforces a detachment from the general rules regarding evidence. This doctrine allows the court to establish (in certain circumstances) that there has been a breach of due diligence without the need to establish that fact with any help from a medical expert. In certain specific cases, the facts speak for themselves (Jackson, 2016: 143). These are cases where negligence is established "prima facie," by the mere act or omission itself, e.g., replacement of a body part during surgery, misplacing surgical instruments in a body during surgery, etc. In the case of Ratcliffe v. Plymouth and the Torbay Health Authority, Judge Hobhouse LJ argued that even in these sorts of cases, the burden of proof remains on the patient. The final result is based only on the fact that certain circumstances establish the liability of the healthcare authority because they form "prima facie" evidence of negligence Jackson, 2016: 143). The doctrine of res ipsa loquitur, in cases of medical errors, allows the Court to reach the conclusion that liability is established as a matter of law when a dangerous situation was solely under the control of the medical authority and that, in normal circumstances, the damage would not have happened. Despite the invocation of the doctrine, the healthcare institution could still attempt to prove that it exercised due diligence in performing treatment and may also attempt to demonstrate how the damage would have occurred independently from its per se negligent conduct (Stauch, 2008). The Slovenian case law in such specific circumstances also relies on the doctrine of "Res ipsa loquitur." The Supreme Court of Slovenia, for example, in one particular case, supported judgment for plaintiff, II Ips 153/2009. ${ }^{15}$ The case regarded an injury (a complicated fracture of a skull) to a fourmonth-old baby at the time of hospitalization. In providing evidence for inadmissible conduct (based on non-contractual liability), the court explained that the hospital should have reduced the foreseeable and preventable risk to the lowest level. However, the hospital failed to do so and therefore failed to prove it had lowered the risks. In regard to causation, the court stated that the standard of proof, according to which "the fault, based on legally relevant facts, must be proven so as to exclude any reasonable doubt about reality," had been met. The court emphasized that in situations where, for legitimate reasons, it is necessary to reduce the burden of proof, it would be enough to decrease it to a standard of "balance of probabilities," since doing otherwise (in cases of proven crisis) could jeopardize the

${ }^{15}$ Decision of the Surpreme Court of Slovenia, Judgment II Ips 153/2009 (8 September 2011). 
parties' right to a fair trial. The conclusion section of the judgment (paragraph 14) is also interesting. There, the court documented that in a "non-liquet" (i.e. a situation where the facts are unclear) situation, the main concern is who bears the burden of proof regarding a legally relevant fact, since the court is obliged to rely on the rules of the substantive burden of proof and not on the procedural burden of proof, which is contained in the evidence produced by the parties at trial.

Informed consent cases in the English legal system utilize the balance of probabilities standard. The signed consent form, in itself, is not sufficient to prove that valid consent was obtained, since it also is necessary to determine whether the patient actually received all the necessary information prior to the medical intervention. It is also necessary to establish the correlation between the damage incurred and the physician's failure to inform the patient (Stauch, 2008). In conclusion, there are no significant differences between the Slovenian and English systems in the matter of informed consent.

\subsection{Proving medical malpractice in the German legal system}

Unlike the English system, the main characteristic of the German system is its inquisitorial nature, which makes the court's role in the process significantly more dynamic. The most striking differences with the English adversarial system rest in the rules about evidence submission, more specifically, in the standards of proof. Generally, the German Civil Procedure Code (Zivilprozessordnung-ZPO) requires a high standard of proof. The facts need to be proven by the standard of certainty, otherwise, the claim is considered unproven (non liquet cognitive crisis) (Stauch, 2008: 65).

In relation to the high standards required when proving facts in cases of medical malpractice, the German courts have developed some adjustments to their case law systems. In a 1979 case $^{16}$, the German Constitutional Court (Bundesverfassungsgericht) emphasized that in situations of medical malpractice the court was obliged to guarantee equality of arms to both parties as a constitutional procedural right, so the patient should be granted a reverse burden of proof. The position, in that particular case, was later settled by the fact that, in the context of judicial

\footnotetext{
${ }^{16}$ Decision of the Constitutional Court of Germany, BVerfG, 25 July 1979, NJW 1979, 1925.
} 
review, lowering the standard of proof was sufficient to solve the issue (Stauch, 2008: 66).

Deviations from general procedure in evidentiary rules have also occurred in cases where the evidence in question deals with documented diagnostics and treatment procedures. The physician's duty to document every step undertaken in the care of the patient increases in relative proportion to the patients' state of health, with seriously ill patients at high risk requiring greater documention. Similarly, greater documentation is required when care is providedby less experienced doctors. In the event that the doctor failed to document the results of the incurred diagnostic tests, he is considered to have acted per se negligently, which in a procedural sense establishes the presumption of failure to perform the diagnostics (Stauch, 2008: 70). As a consequence, the medical expert who analyses the case for the trial will have to proceed by considering (that is, presuming) the diagnostic process incorrect, and therefore test only the correlation between the omission of diagnostic information and the damage suffered.

Another difference in the German legal system that has to be mentioned is similar to the "res ipsa loquitur" doctrine, based on prima facie evidence (named Anscheinbeweis or Prima Facie Beweis) (Stauch, 2008: 73). This doctrine is applied through case law in cases involving special circumstances, such as situations that clearly indicate an error in the treatment process. Typical examples include cases where, for instance, a medical instrument is left in the patient's body during surgery or when the patient suffers from burns due to the use of certain medical equipment (taking into account expert opinion that this does not usually happen). More commonly, the doctrine is used in cases of HIV infections during transfusions (Stauch, 2008: 75). Similar to common law systems (mentioned above), also in the German legal system a health care institution could hide proof of its negligence by offering alternative explanations for the causes of the problem (Stauch, 2008: 76). The legal rules attest that in recent years the claimants' reliance on prima facie evidence has diminished since legal cases have developed more reliable methods that make it possible to prove negligence in certain factual situations (i.e. where it is obvieous at first sight that the damage could have been prevented). This is referred to as a "doctrine of fully manageable risks (vollbeherrschbare Risken)", and posits that in cases of a problem occurring under a physician's responsibility, that negligence is presumed to be what caused the issue (for example: If in a case a patient suffered 
brain damage because while under anesthesia he was found to be disconnected from the oxygenation system, even if it was not possible to determine how the oxygen system malfunctioned, but it was found that the device was unattended at some point, the court would hold the health institution responsible, since proper care would have prevented any problem from happening) (Stauch, 2008).

According to the German legal system, during a civil procedure, it is necessary to mention the contradictions that have emerged in case law in order to help patients solve any problems they may have had in proving causation and due diligence breaches. It was necessary to lower the standard of proof e.g., secondary damage and causality, in cases of failure to perform appropriate diagnostic procedures. Pursuant to $\ 287 \mathrm{ZPO}$, the court may, in certain cases, reach a verdict using a lower standard of proof, namely, "balance of probabilities". This solution is used mostly in both in cases where the pecuniary damage was caused by errors in treatment and those with causation assessment. In the latter cases, the court has to distinguish between primary (haftungsberundende) and secondary (haftungsausfullende) causality. The primary cause deals with the basic injury to the harmed party, while the secondary cause deals with the damage generated by the initial condition. In order to prove the secondary causality, it is necessary to use the lower standard "balance of probabilities" (Stauch, 2008: 84). The following case helps us to better understand the difference between the two levels of causality. In a case from 1962 (BGH), a patient suffered from an allergic reaction, caused by the cream the physician prescribed, and which lead to bone marrow failure and later to death. In that case the standard of balance of probabilities was used to prove the cause of death. Similarly, the court allowed lowering the standard of proof in cases of misdiagnosis. These are either cases where the results of the performed diagnostic tests were not preserved or where the diagnostic examinations were neglected. Thus, the court (BGH), in one particular case of neglect where the diagnostic, an x-ray of a patient's lung, was not peerformed before a procedure was undertaken, decided whether or not this neglect led to a misdiagnosis and, if the diagnostic examination had been analyzed properly, whether the physician would have chosen an alternative treatment (Stauch, 2008: 86). 
As far as informed consent is concerned, under the German laws the doctor shoulders the burden of proof, and therefore must prove that the patient was provided with all the relevant information to make reasoned decisions about the medical treatment. The standard of proof required to attest informed consent, depends on the court's opinion about relevant facts. The signed consent form alone is not sufficient to achieve this standard, but the medical professional needs to prove with certainty that the patient was (de facto) aware of any of the risks from the treatment (Stauch, 2008: 124). Concerning proving a correlation between the reporting of the risk (which was absent in the physician's explanation) and the resulting damage, the standard of proof based on $\ 287 \mathrm{ZPO}$ is reduced to the balance of probabilities, meaning damage is secondary because it follows the primary infringement - treatment without the patient's consent (Stauch, 2008: 125). The physician shoulders the burden to prove that without his treatment the result would have led to the same damage to the patient, provided that the standard of clear and convincing evidence under $\$ 286$ ZPO has been met. This standard also assesses the likelihood that a patient could have refused medical treatment if he or she had been made aware of the risks related to the treatment (that were subsequently realized). The patient is not required to prove what alternate decision he would have made. Instead, it is sufficient to prove that, if all the relevant information had been presented to him, the patient would have needed to consider more seriously whether or not to proceed with the treatment. To prove these facts the court relies on the testimony of the patient (Stauch, 2008).

The above shows that the German regime is very similar to the Slovenian one. The standards of proof are diminished in the same procedural situations, although in the Slovenian system there is no mention of "primary" or "secondary" causality. Both the verdicts based on prima facie evidence and the doctrine of fully manageable risks are present in the Slovenian law system, as already stated in the Supreme Court's ruling RS II Ips 153/2009 of 8.9.2011. 


\section{Standards of proof in no-fault systems}

According to legal theorists, one of the key reasons a system of strict liability has been introduced in medical malpractice cases is related to the difficulty of proving a breach of contract and the cause-and-effect relationship between the breach and the resulting damage suffered (Žnidaršič Skubic, 2018). Some countries ${ }^{17}$ have introduced a so-called "no-fault compensation" scheme inside their legal systems. The purpose of such a system is to simplify the procedure for the injured party to receive compensation for damages resulting from medical care and treatment (Žnidaršič Skubic, 2018: 92). This system allows compensation for damages to the patient whether or not the injury is the result of the physician's negligent conduct. The only prerequisite for entitlement to benefits is that the damage resulted from the treatment received. In support of this no-fault compensation scheme, its advocates point to both the practical difficulties in proving not only who was responsible for the negligent conduct but also the complex causation issues. These advocates also point out that problems in classical systems can be at best minimized by utilizing the rules of prima facie, lowering or even reversing the burden of proof on guilt, etc., but none of these procedural devices can eliminate entirely the problems inherent in medical malpractice cases (Žnidaršič Skubic, 2018: 92).

Some countries (including Slovenia (Kraljić \& Kobal, 2018)) in cases of damage caused by vaccination) have established a partial "no-fault compensation scheme" related to specific areas of health care. The Austrian legal system adopted a compensation plan in cases of medical malpractice occurring in state hospitals, in the event that the damage could be attributed to medical misconduct, but where the mistreatment could not be proven (Žnidaršič Skubic, 2018).

We notice significant differences between no-fault systems introduced by the Scandinavian countries and the New Zealand systems, as well as contrasts in the requirements of the standards of proof. In the case of the Scandinavian countries, the initial stages of a trial involve decisions on the part of the various state administrative institutions (this is the administrative nature of the procedure). The second phase consists of the court procedure. The court assesses whether the patient's health deteriorated either as a result of an avoidable action (Sweden,

\footnotetext{
${ }^{17}$ E.g., New Zealand, Norway, Sweden, Finland, Denmark
} 
Denmark, Finland), or whether the treatment was improper (Norway), or whether there was a medical error or medical accident. The existence of a causal link must be proved by the injured party in all countries except Norway (in Norway the medical party defendant has the burden of proof). Denmark, Finland and Sweden use the so-called probability criterion, under which anything greater than a 50 percent likelihood of the existence of a causal link suffices to prove a problem was caused by the medical professional, and on this condition there is verification that the patient suffered harm. In the case of New Zealand's "non-fault" compensation system, causation is based on a balance of probabilities, and the criteria are less strict than in average civil procedures. In all of these systems, the patient is not required to submit any documentation during the procedure as it is provided by the decisionmaking authority. (Žnidaršič Skubic, 2018: 100).

In the Slovenian partial no-fault system, which is utilized in both the fields of obligatory vaccination ${ }^{18}$ and HIV infections for the transfusion of blood or blood products ${ }^{19}$, compensation for the injured party is dictated by rules of administrative law and the procedure may be thereafter followed by an administrative court. There is no rule in legislation or law case on what conditions justify the granting of compensation.

In our opinion, the introduction of a general medical malpractice no-fault system in the Slovenian legal system would not establish an alteration in the standards of proof. As can be seen from the above examples, comparative legal regulations do not interfere with the procedural rules, and it can be concluded from the latter that, in the case of the employment of a no-fault scheme, medical malpractice would be analyzed with a very different approach. As long as one of the main reasons for the introduction of such a system is to safeguard the injured party (material and procedural), it is certainly reasonable to insist on reaching a verdict in civil litigation rather than administrative, and to maintain, in case law, pre-established standards in order to prove any hypothesis through the standard of balance of probabilities.

\footnotetext{
${ }^{18}$ Legalised in Infectious Diseases Act (ZNB), Ur. 1. RS, št. 33/06 - official consolidated text and 49/20 ZIUZEOP).

${ }^{19}$ Legalized in Law on Damage to People Infected with HIV by Transfusion of Blood or Blood Products (ZPŠHIV), Ur. 1. RS, št. 36/97 and 54/04 - Zdoh-1.
} 


\section{$7 \quad$ Conclusion}

In medicine, there always will be uncertainty regarding whether a particular treatment will prove to be successful. Consequently, in a malpractice setting, for a hypothetical finding, it must be sufficient for the patient to assert and prove that the conduct of the medical professional (had he acted properly) would have led to a different (i.e. positive) result. The likelihood of such an event is a professional medical issue, and therefore must be analyzed by a medical expert. The assessment of a sufficient degree of likelihood by Slovenian courts is required according to Article 215 of the Civil Procedure Act, under which the court needs to impose an appropriate standard of proof. Reducing the general standard of proof from that of clear and convincing evidence to the standard of proof of balance of probabilities is a general trend in civil litigation worldwide. Applying such case law in difficult procedural situations is necessary to guarantee the parties equality of arms and at the same time the right to judicial protection, which would be threatened by so-called "non liquet" situations. We contend that during a trial, lowering the standards of proof is the key to striking an appropriate balance between protecting the patient as the procedurally weaker party and providing equality of rights. Changing the system in the direction of no-fault compensation schemes, is not yet necessary for the Slovenian legal system. The introduction of systemic changes, as would occur if a no-fault scheme were to be adopted, requires a re-evaluation of the socio-economic foundations of society. Instead, the consistent application of a lower standard of proof, in cases that allow it, is sufficient to move towards a more equitable legal system.

\section{References}

Davies, S. (2009) Proof on the Balance of Probabilities: What This Means in Practice, retrieved from: https://uk.practicallaw.thomsonreuters.com/2-500-

6576 transitionType $=$ Default\&contextData $=($ sc.Default $) \&$ firstPage $=$ true $\quad(11$ September 2020).

Jackson, E. (2016). Medical Law, Text, Cases and materials, 4th ed. (Oxford: Oxford University Press).

Janžekovič, J. (1981) Filozofski leksikon (Celje: Mohorjeva založba).

Kraljić, S. \& Kobal, A. (2018) Verschärfung der Gesetzgebungsansätze zur Impfungen in ausgewählten Staaten, Zbornik Pravnog fakulteta u Zagrebu, 68(3/4), pp. 431-464.

Kranjc, J. (1998) Latinski pravni reki (Ljubljana: Cankarjeva založba).

Pavčnik, T. (2012) Dokazni standardi, Podjetje in delo, (6-7), pp. 1407-1416.

Polajnar-Pavčnik, A. \& Wedam-Lukić, D. (eds.) (1998) Pravo in medicina (Ljubljana: Cankarjeva založba).

Rijavec, V. (2017) Medicinska napaka, In: Ude, L., (ed.) Pravni letopis 2017 (Ljubljana: Inštitut za primerjalno pravo pri Pravni fakulteti v Ljubljani), pp. 43-57. 
Stauch, M. (2008) The Law of Medical Negligence in England and Germany, A Comparative Analysis (Oxford and Portland, Oregon: Hart Publishing).

Šepec, M. (2018) Medical Error - Should it be a Criminal Offence?, Medicine, Law \& Society, 11(1), pp. 47-66.

Ude, L., Betteto, N., Galič, A., Rijavec, V., Wedam Lukič, D. \& Zobec, J. (2006). Pravdni postopek, Zakon $s$ komentarjem, 2. knjiga (Ljubljana: Uradni list Republike Slovenije).

Vojković, H. (2019) Differentiating Medical Malpractice From Medical Complications, Medicine, Law \& Society, 12(1), pp. 39-64.

Žnidaršič Skubic, V. (2018) Civilno medicinsko pravo (Ljubljana: Uradni list Republike Slovenije).

\section{Legislation}

Council Directive of 25 July 1985 on the approximation of the laws, regulations and administrative provisions of the Member States concerning liability for defective products (85/374/EEC), Official Journal of the European Communities No L 210/29.

Obligacijski zakonik (Code of Obligations) (OZ): Ur. 1. RS, no. 97/07, 64/16 and 20/18.

Pravilnik o obrazcih o pisnih izjavah volje pacienta (Rules on the forms of written statements of the patient's will): Ur. 1 . RS, no. 82/08 and 84/08.

Zakon o nalezljivih boleznih (Infectious Diseases Act) (ZNB): Ur. 1. RS, no. 33/06 - official consolidated text and 49/20- ZIUZEOP).

Zakon o pacientovih pravica (Patients' Rights Act) (ZPacP): Ur. l. RS, no. 15/08 and 55/17.

Zakon o povrnitvi škode osebam, okuženim z virusom HIV zaradi transfuzije krvi ali krvnih pripravkov (Law on Compensation for Damage to Persons Infected with HIV by Transfusion of Blood or Blood Preparations): Ur. 1. RS, no. 36/97 and 54/04 - ZDoh-1).

Zakon o pravdnem postopku (Civil Procedure Act) (ZPP): Ur. 1. RS, št. 73/07 - official consolidated text, 45/08 - ZArbit, 45/08, 111/08 - US decision, 57/09 - US decision, 12/10 - decision US, 50/10 - US, $107 / 10$ - US, $75 / 12$ - US, 40/13 - US, $92 / 13$ - US, $10 / 14$ - US, 48/15 - US decision, 6/17 - US decision, 10/17, 16/19 - ZNP-1 and 70/19 - US decision.

\section{Case law}

Decision II Ips 182/2013 of 24 April 2014, available at: http://www.sodisce.si/vsrs/odlocitve/2012032113066098/ (11 September 2020).

Decision with ref. no. Up-680/14 dated 5 May 2016., (available at: https://www.us-rs.si/odlocbaustavnega-sodisca-up-680-14-z-dne-5-5-2016/ (11 September 2020).

Judgment and Decision of the Ljubljana Higher Court, ref. no. II Cp 3712/2008 of 22 April 2009, (available at: http://www.sodisce.si/vislj/odlocitve/45064/ (11 September 2020).

Judgment II Ips 153/2009 of 8 September 2011, available at: http://sodisce.si/vsrs/odlocitve/2010040815260881/ (11 September 2020).

Judgment II Ips 17/2015 of 29 October 2015, available at: http://www.sodisce.si/vsrs/odlocitve/2015081111389349/ (11 September 2020).

Judgment II Ips 183/2015 of 12 March 2015, available at: http://sodisce.si/vsrs/odlocitve/2015081111389708/ (11 September 2020).

Judgment II Ips 402/2007 of 13 May 2010, available at: http://sodisce.si/vsrs/odlocitve/2012032113062548/ (11 September 2020).

Judgment II Ips 436/2005 of 21 June 2007, (available at: http://www.sodisce.si/vsrs/odlocitve/11006/ (11 September 2020).

Judgment of Šilih v Republic of Slovenia of 4 September 2009, (available at: https://hudoc.echr.coe.int/fre\#\{\%22itemid\%22:[\%22001-92142\%22]\} (11 September 2020).

N.W., L.W., C.W. v. Sanofi Pasteur MSD SNC, C-621/15 of 21 June 2017, ECLI:EU:C:2017:484, available at: https://eur-lex.europa.eu/legalcontent/EN/TXT/?uri=CELEX\%3A62015CJ0621 (11 September 2020). 
